Title no. 97-S37

\title{
Bond Slip of High Relative Rib Area Bars under Cyclic Loading
}

\author{
by Jun Zuo and David Darwin
}

\begin{abstract}
The load-slip behavior of high relative rib area and conventional reinforcing bars subjected to reversed cyclic loading is compared. No. 8 (No. 25) production reinforcing bars with relative rib areas of 0.119 and 0.085 are subjected to reversed tension-tension cyclic loading to evaluate the effect of relative rib area on slip and bond deterioration. The tests demonstrate that the high relative rib area bars exhibit 50 to $70 \%$ less unloaded end slip, and 30 to $40 \%$ less loaded end slip than the conventional bars under multiple cycles of loading. The results suggest that high relative rib area bars could be used to improve the behavior of reinforced concrete members and frame joints that are affected by bond deterioration, such as caused by seismic loading.
\end{abstract}

Keywords: bond (concrete to reinforcement); cyclic loads; deformed reinforcement; reinforcing steels; seismic loading; structural engineering.

\section{INTRODUCTION}

Reversed cyclic loading can result in severe deterioration in the bond between reinforcing steel and concrete (Ciampi et al. 1982; Balazs and Koch 1991; ACI Committee 408 1992). This deterioration is of particular concern for beam-column joints in reinforced concrete frames subjected to earthquake loads (Meinheit and Jirsa 1977; Briss, Paulay, and Park 1978; Ehsani and Wight 1985; Durrani and Wight 1985; Leon 1989), since the slip of beam and column bars through joints contributes significantly to the loss of frame stiffness (Durrani and Wight 1985; Ehsani and Wight 1985; Shu and Jirsa 1983).

Darwin and Graham (1993) used ASTM A 944 beam-end specimens to evaluate the bond strength of reinforcing bars with a wide range of relative rib areas $R_{r}$ (ratio of projected rib area normal to bar axis to the product of the nominal bar perimeter and center-to-center rib spacing) under monotonic loading. They observed that, under all conditions of confinement, the initial stiffness of load-slip curves increases with an increase in relative rib area. Their results suggest that a similar improvement can be obtained for high relative rib area bars under cyclic loading.

This paper presents the results of the first study designed to compare the load-slip behavior of high $R_{r}$ and conventional bars under reversed cyclic loading. The study is significant because stiffer load-slip response with high $R_{r}$ in bars could be used to improve the response of beam-column joints in reinforced concrete structures subjected to earthquake forces. Full details of the study are presented by Zuo and Darwin (1998).

\section{Test specimens}

\section{EXPERIMENTAL PROGRAM}

High $R_{r}$ and conventional No. 8 (No. 25) reinforcing bars were embedded in concrete, as shown in Fig. 1. The concrete specimens were $16 \mathrm{ft}(4.88 \mathrm{~m})$ long, $16 \mathrm{in.} \mathrm{(406} \mathrm{mm)} \mathrm{high,} \mathrm{and}$ 12 in. $(305 \mathrm{~mm})$ wide. The bars were placed horizontally through the middle of the specimens at a spacing of $30 \mathrm{in} .(762 \mathrm{~mm})$, with bonded lengths of $10 \mathrm{in}$. (254 mm). The high $R_{r}$ and conventional bars were alternated within each specimen. Short

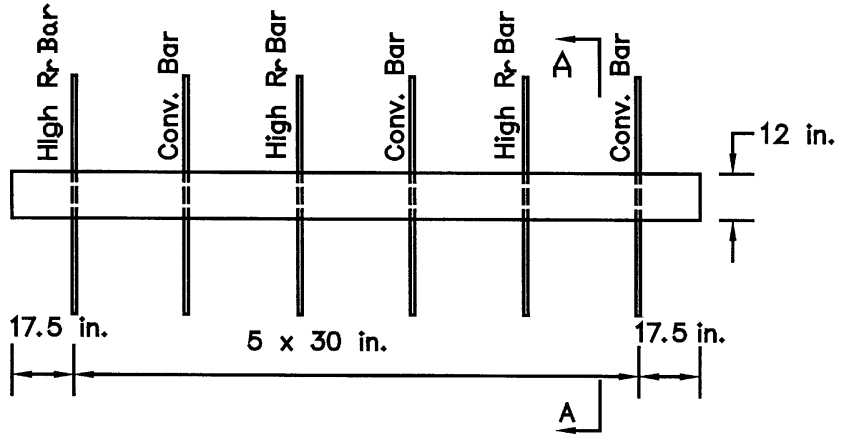

PLAN VIEW

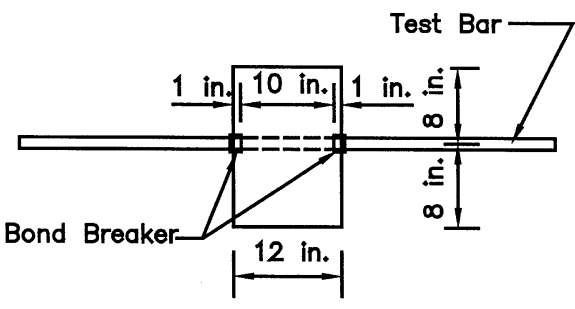

SECTION A-A

Fig. 1-Schematic of reversed cyclic loading specimen $(1 \mathrm{in} .=25.4$

pieces of polyvinyl chloride (PVC) pipe were used to control the bonded lengths and to prevent a cone-type failure at the concrete surfaces. Two No. 5 (No. 16) bars were placed at the top and bottom along the length of the specimens to provide flexural strength. No stirrup or tie reinforcement was used.

\section{Materials}

Reinforcing steel-The bars met the requirements of ASTM A 615 . The high $R_{r}$ bars, designated $8 \mathrm{~N} 3$, had a relative rib area of 0.119 , and a yield strength of $80.57 \mathrm{ksi}(555 \mathrm{MPa})$. The conventional bars, designated $8 \mathrm{C} 0 \mathrm{~A}$, had a relative rib area of 0.085 (near the upper limit for most conventional bars [Darwin et al. 1996]) and a yield strength of $69.50 \mathrm{ksi}$ (479 MPa). The yield strengths were determined from tests of three samples of each bar. Bar properties are given in Table 1.

ACI Structural Journal, V. 97, No. 2, March-April 2000.

MS No. 99-034 received March 9, 1999, and reviewed under Institute publication policies. Copyright $($ ) 2000, American Concrete Institute. All rights reserved, includpolicies. Copyright 2000 , American Concrete ing the making of copies unless permission is obse Pertinent discussion will be published in the January-February 2000 ACI Structural Journal if received by September 1, 2000. 
ACI member Jun Zuo is a structural engineer with Constructive Engineering Design, Kansas City, Mo. He received his BS in architectural engineering from Tongji University in China, and his MS and PhD in civil engineering from the University of Kansas.

David Darwin, FACI, is the Deane E. Ackers Professor of Civil Engineering and Director of the Structural Engineering and Materials Laboratory at the University of Kansas. He is a past member of the Board of Direction and the Technical Activities Committee, and is past-president of the Kansas Chapter of ACI. He is also past-chairman of the Publications Committee and the Concrete Research Council, and a member and past-chairman of ACI Committee 224, Cracking. He chairs the TAC Technology Transfer Committee and serves on ACI Committees 408, Bond and Development of Reinforcement; 446, Fracture Mechanics; and Joint ACI-ASCE Committees 445, Shear and Torsion; and 447, Finite Element Analysis of Reinforced Concrete Structures. He is a recipient of the Arthur R. Anderson and ACI Structural Research

Concrete-Air-entrained concrete was supplied by a local ready mix plant. The concrete contained Type I portland cement, $3 / 4$ in. (19 mm) maximum size crushed limestone coarse aggregate, and Kansas river sand. The water-cement ratio ( $w /$ c) was 0.44 . The average concrete compressive strength was 5170 psi (35.6 MPa) at ages of 20 days for test Bars 3 through 6 , and 21 days for test Bars 7 through 12. The reported strength represents the average of six tests (Note: the average of the cylinders tested on Day 20 was 5140 psi [35.4 MPa], and the average of the cylinders tested on Day 21 was 5200 psi [35.9 $\mathrm{MPa}]$ ). Bars 1 and 2 were used to evaluate the load system at ages of 18 and 19 days. Concrete mixture proportions and properties are given in Appendix A.*

\section{Test procedures}

The test setup is shown in Fig. 2. Load was applied to a bar by 60-ton jacks located on opposite sides of the specimen. Loads were transferred to the specimen through reaction frames. The frames had two supports, spaced with a clear distance of 24 in. $(607 \mathrm{~mm})$ so that compressive struts originating at the loading apparatus would not intersect the test region. As shown in Fig. 2, a 0.5 in. ( $35 \mathrm{~mm}$ ) gap between the jack and the anchor plate ensured that when the load was applied to one side of the specimen, no load was applied to the other side of the specimen. Five reversed tension-tension cycles with peak loads of 10,15 , and 20 kips $(44.5,66.7$, and $89.0 \mathrm{kN})$ were applied at a rate of approximately 5 kips $(22 \mathrm{kN})$ per min.

Bar slips were measured using two spring-loaded linear variable differential transformers (LVDTs) on each side of the specimen. The LVDTs were attached to the bars, and bore against the faces of the concrete specimen. Loads were measured using load cells that were placed between the reaction frames and the jacks. Tests on Bars 3 through 12 were completed within $36 \mathrm{~h}$.

\section{TEST RESULTS AND EVALUATION Results and observations}

Typical load-slip curves for high relative rib area and conventional bars are shown in Fig. 3(a) and (b), respectively. The elastic deformation of the bars at the loaded end between the bonded length and the LVDTs has been subtracted from the measured values to give the best estimate of the actual slips. Reported slips are based on the average reading from the two LVDTs on each end of the bar. In the figures, bar slip on one side of a specimen is plotted (loaded end slip corresponding to loading on one side of the specimen, and unloaded slip corresponding to loading on the other side) because the data are obtained by the same LVDTs. As plotted in Fig. 3(a) and (b), slip in the direction from the right to the left side of the specimen is defined as positive slip, while slip in the opposite direction is defined as negative

*The Appendix is available in xerographic or similar form from ACI headquarters, where it will be kept permanently on file, at a charge equal to the cost of reproduction plus handling at time of request.
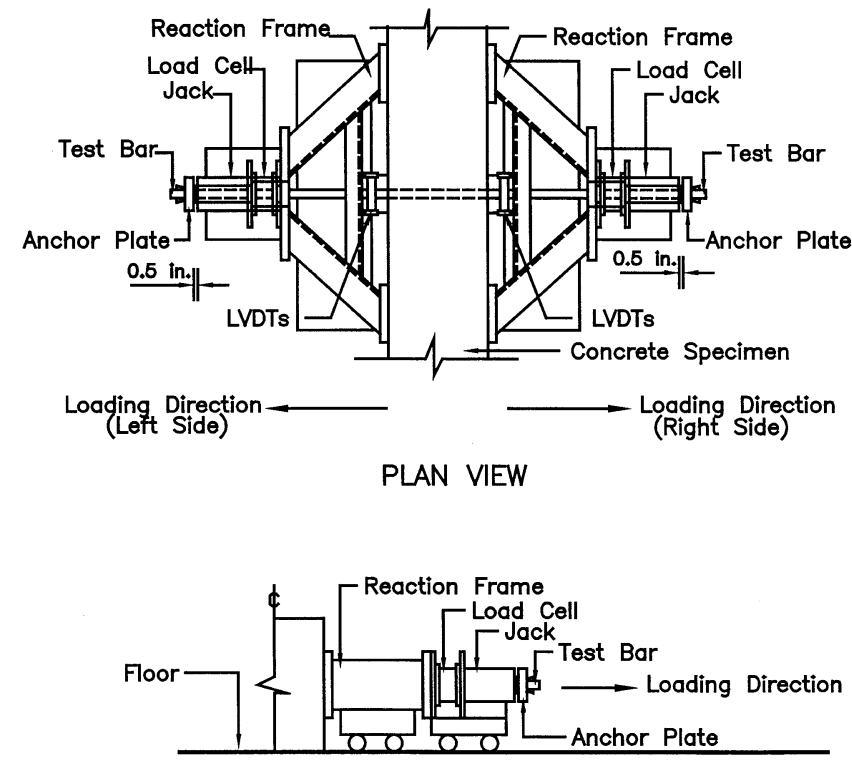

SIDE VIEW

Fig. 2-Schematic reversed cyclic loading test setup.

slip. Likewise, loading on the bars on the left side of the specimen is defined as positive, while loading on the right side is defined as negative. As expected, unloaded end slips are smaller than loaded end slips, and load-unloaded end-slip curves are initially much steeper than the load-loaded end-slip curves. The curves show that bond stiffness decreases and slip increases as the number of cycles increases. The magnitude of the slip increase is much higher at higher load levels (15 and 20 kips [16.7 and $89.0 \mathrm{kN}$ ]) than at the lowest load level (10 kips [44.5 kN]). These observations illustrate the expected deterioration of bond under reversed cyclic loading. The load-slip curves exhibit pinching near zero load. This phenomenon is mainly due to the rigid body movement of the bars, as explained by Eligehausen, Popov, and Bertero (1983). As load increases and the cycling progresses, the concrete in front of the bar ribs crushes and shears; when the load is reversed, large slip occurs before the ribs bear against the concrete and the bond stress again increases.

\section{Evaluation}

The average loaded end and unloaded end slips at each peak load $(10,15$, and 20 kips $[44.5,66.7$, and $89.0 \mathrm{kN}])$ are summarized in Table 2 . Five conventional bars and four high $R_{r}$ bars (one bar was overloaded and is not used in the averages) are used. Loaded and unloaded end slips for each test bar at the peak loads are summarized in Appendix A. The comparisons show that the maximum loaded and unloaded end slips at peak loads for high $R_{r}$ bars are consistently smaller than those for conventional bars. The loaded end slip of the high $R_{r}$ bars averages 60 to $70 \%$ of the slip of the conventional bars at all three load levels. The unloaded end slip of the high $R_{r}$ bars averages 30 , 40 , and $50 \%$ of the slip of the conventional bars at the peak loads of 10,15 , and 20 kips $(44.5,66.7$, and $89.0 \mathrm{kN})$, respectively.

The results are further illustrated in Fig. 4, which shows the average slips of high $R_{r}$ and conventional bars at each peak load as a function of the number of loading cycles (in this case, for left-side loading). The figure shows that the loaded end slips on the left side and the unloaded slips on the right side of the specimens. The loads corresponding to unloaded end slips are multiplied by -1 for easier comparison. Figure 4 shows that the loaded and unloaded end slips increase with increases in the 
Table 1-Properties of reinforcing bars

\begin{tabular}{|c|c|c|c|c|c|c|c|c|c|c|c|c|}
\hline \multirow{2}{*}{$\begin{array}{c}\text { Bar }^{*} \\
\text { designation }\end{array}$} & \multirow{2}{*}{$\begin{array}{c}\text { Yield } \\
\text { strength, } \\
\text { ksi }\end{array}$} & \multirow{2}{*}{$\begin{array}{l}\text { Nominal } \\
\text { diameter, } \\
\text { in. }\end{array}$} & \multirow{2}{*}{$\begin{array}{c}\text { Weight, } \\
\mathrm{lb} / \mathrm{ft}\end{array}$} & \multirow{2}{*}{$\begin{array}{c}\% \text { light or } \\
\text { heavy }\end{array}$} & \multirow{2}{*}{$\begin{array}{c}\text { Rib } \\
\text { spacing, in. }\end{array}$} & \multicolumn{2}{|c|}{ Rib width ${ }^{\dagger}$} & \multicolumn{2}{|c|}{$\frac{\text { Rib width }}{\text { rib spacing }}$} & \multicolumn{2}{|c|}{ Rib height } & \multirow{2}{*}{$\begin{array}{l}\text { Relative } \\
\text { rib area }\end{array}$} \\
\hline & & & & & & Top, in. & Bottom, in. & Top & Bottom & ASTM, in. & Avg, ${ }^{\S}$ in. & \\
\hline $8 \mathrm{C} 0 \mathrm{~A}$ & 69.50 & 1.000 & 2.615 & $2.1 \% \mathrm{~L}$ & 0.598 & 0.119 & 0.235 & 0.199 & 0.393 & 0.066 & 0.063 & 0.085 \\
\hline $8 \mathrm{~N} 3$ & 80.57 & 1.000 & 2.730 & $2.2 \% \mathrm{H}$ & 0.487 & 0.124 & 0.221 & 0.255 & 0.454 & 0.072 & 0.068 & 0.119 \\
\hline
\end{tabular}

* Bar designation: \#AAB; \# = bar size (No. 8); AA = bar manufacturer and deformation pattern; C0 = Conventional chaparral steel bar; N3 = New north star steel bar; $\mathrm{B}=$ different letter presented if bar had same deformation pattern as reported by Darwin et al. (1996), but were produced from different steel heat.

Average rib width at: Top $=$ top of ribs; Bottom $=$ bottom of ribs.

\$ Ratio of rib width-to-rib spacing at top or bottom of ribs.

Average rib height between longitudinal ribs.

Note: 1 in. $=25.4 \mathrm{~mm} ; 1 \mathrm{ksi}=6.89 \mathrm{MPa}$; and $1 \mathrm{lb} / \mathrm{ft}=1.49 \mathrm{~kg} / \mathrm{m}$

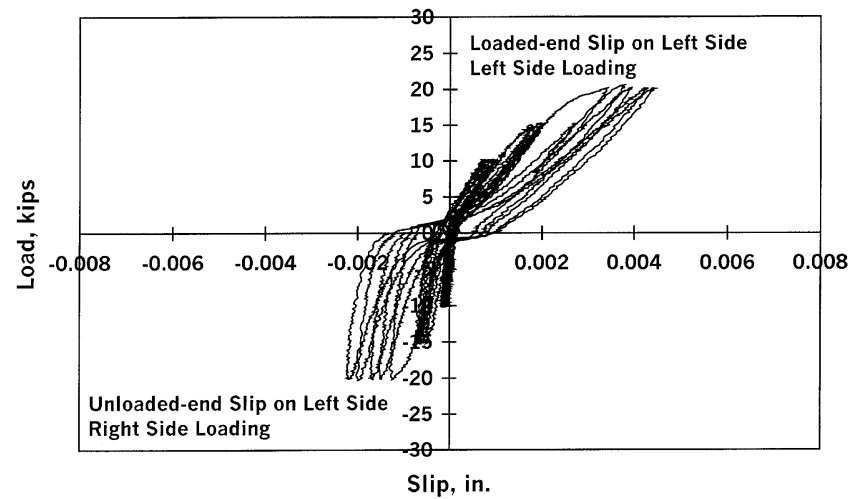

Fig. 3(a)-Load-versus-loaded end and unloaded end slip for high relative rib area bar (8N3) 4 on left side of specimen (1 kip $=4.45 \mathrm{kN} ; 1 \mathrm{in} .=25.4 \mathrm{~mm}$ ).

peak load and number of load cycles for both high $R_{r}$ and conventional bars, and that slips are greater for conventional bars than for high $R_{r}$ bars. At the lowest peak load (10 kips [44.8 kN]), the increase in slip with an increase in loading cycle is approximately the same for high $R_{r}$ and conventional bars (approximately a $0.0002 \mathrm{in}$. [0.005 $\mathrm{mm}]$ increase in loaded end slip as the number of cycles increases from 1 to 5). At high peak loads (15 and 20 kips [ 66.7 and $89.0 \mathrm{kN}$ ]), however, like the total values of slip, the increases in slip with an increase in loading cycle are lower for high $R_{r}$ bars than for conventional bars. At a peak load of 15 kips $(66.7 \mathrm{kN})$, as the number of loading cycles increases from 6 to 10, the average increase (left and right side) in loaded end slip for high $R_{r}$ bars is only $55 \%$ of that for conventional bars. At a peak load of 20 kips $(89.0 \mathrm{kN})$, as the number of loading cycles increases from 11 to 15 , the ratio of incremental slips for high $R_{r}$ bars to those for conventional bars is $70 \%$.

The comparisons in Table 2 and Fig. 4 demonstrate that the slip of high $R_{r}$ bars is significantly smaller than the slip of conventional bars under reversed cyclic loading, and that high $R_{r}$ bars exhibit less bond deterioration than conventional bars. Therefore, it can be expected that reinforced concrete members and frame joints that are affected by bond deterioration under seismic loading will exhibit better performance if reinforced with high $R_{r}$ bars than if reinforced with conventional bars.

\section{SUMMARY AND CONCLUSIONS}

This paper describes basic tests to compare the load-slip behavior of high relative rib area and conventional reinforcing bars subjected to reversed cyclic loading. The tests were designed to provide an indication of the performance of high relative rib area bars in structures subjected to severe seismic loading. The tests show that increasing $R_{r}$ from 0.085 (a conventional bar) to 0.119 (a high $R_{r}$ bar) will reduce unloaded end slip by 50 to $70 \%$ and loaded end slip by 30 to $40 \%$ for bars subjected to reversed cyclic loading.

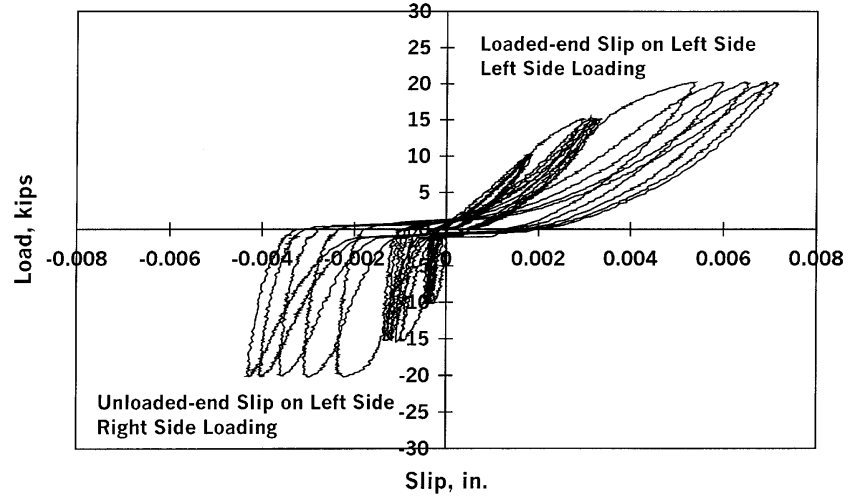

Fig. 3(b)-Load-versus-loaded end and unloaded end slip for conventional bar (8COA) 3 on left side of specimen $(1 \mathrm{kip}=$ $4.45 \mathrm{kN} ; 1 \mathrm{in} .=25.4 \mathrm{~mm})$.

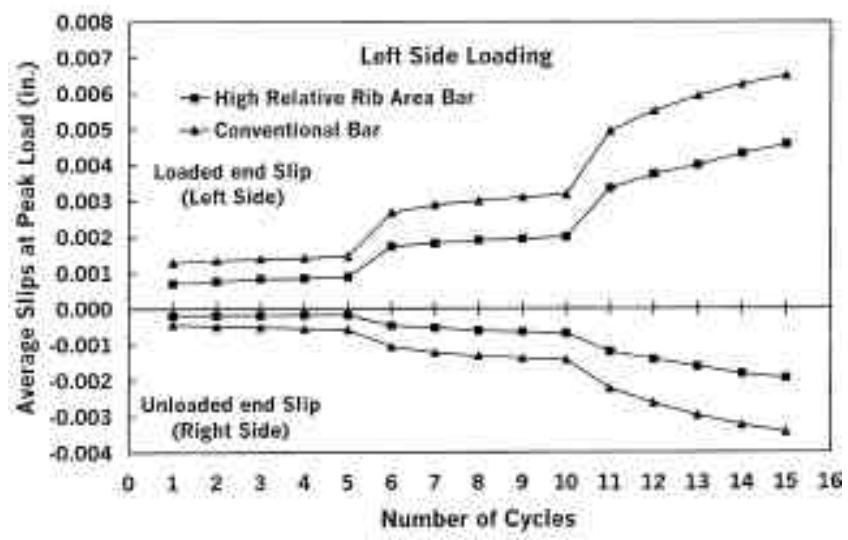

Fig. 4-Average slips of conventional bars 3, 5, 7, 9, and 11 and high relative rib area bars 4, 6, 8, and 10 at peak loads versus number of loading cycles for left side loading $(1 \mathrm{in} .=$

\section{ACKNOWLEDGMENTS}

Support for this research was provided by the National Science Foundation under NSF Grant No. CMS-9402563, the U.S. Department of Transportation-Federal High way Administration, ABC Coating Inc., AmeriSteel, Birmingham Steel Corp., Chaparral Steel, Fletcher Coating Co., HerbertsO'Brien Inc., North Star Steel Co., and 3M Corp. Support was also provided by Geiger Ready-Mix, Iron Mountain Trap Rock Co., and Dayton Richmond $\mathrm{Co}$.

\section{REFERENCES}

ACI Committee 408, 1992, "Bond under Cyclic Loading (ACI 408.2R92), State-of-the-Art Report," American Concrete Institute, Farmington Hills, Mich., $32 \mathrm{pp}$.

ASTM A 944, 1995, "Standard Test Method for Comparing Bond Strength of Steel Reinforcing Bars to Concrete Using Beam-End Specimens," 1999 Annual Book of ASTM Standards, V. 1.04, ASTM, West Conshohocken, Pa., pp. 521-524.

Balazs, G. L., and Koch, R., 1995, "Bond Characteristics under Reversed Cyclic Loading," Otto Graf Journal, V. 6, Stuttgart, pp. 47-62.

Briss, G. R.; Paulay, T.; and Park, R., 1978. "Elastic Behavior of Earth- 
Table 2-Comparisons of average maximum slips under reversed cyclic loading at peak load for high $R_{r}$ and conventional bars: (a) loaded end slips; and (b) unloaded end slips.

(a)

\begin{tabular}{|c|c|c|c|c|c|c|c|}
\hline \multirow[b]{2}{*}{ Cycle } & \multirow{2}{*}{$\begin{array}{c}\text { Peak load, } \\
\text { kips }\end{array}$} & \multicolumn{2}{|c|}{ Left loaded end slip ${ }^{*}$} & \multirow{2}{*}{$\begin{array}{l}\text { Ratio of high } R_{r} \\
\text { to Conv. }{ }^{\dagger}\end{array}$} & \multicolumn{2}{|c|}{ Right loaded end slip ${ }^{*}$} & \multirow{2}{*}{$\begin{array}{c}\text { Ratio of high } R_{r} \\
\text { to Conv. }\end{array}$} \\
\hline & & High $R_{r}$, in. & Conv., in. & & High $R_{r}$, in. & Conv., in. & \\
\hline 1 & 10 & 0.00070 & 0.00128 & 0.547 & 0.00124 & 0.00197 & 0.630 \\
\hline 2 & 10 & 0.00076 & 0.00134 & 0.567 & 0.00137 & 0.00207 & 0.661 \\
\hline 3 & 10 & 0.00083 & 0.00138 & 0.597 & 0.00140 & 0.00210 & 0.669 \\
\hline 4 & 10 & 0.00084 & 0.00141 & 0.598 & 0.00145 & 0.00214 & 0.679 \\
\hline 5 & 10 & 0.00088 & 0.00145 & 0.609 & 0.00148 & 0.00217 & 0.685 \\
\hline 6 & 15 & 0.00173 & 0.00267 & 0.648 & 0.00244 & 0.00339 & 0.719 \\
\hline 7 & 15 & 0.00181 & 0.00289 & 0.628 & 0.00258 & 0.00354 & 0.728 \\
\hline 8 & 15 & 0.00190 & 0.00300 & 0.633 & 0.00268 & 0.00378 & 0.710 \\
\hline 9 & 15 & 0.00193 & 0.00309 & 0.626 & 0.00270 & 0.00387 & 0.699 \\
\hline 10 & 15 & 0.00199 & 0.00317 & 0.628 & 0.00274 & 0.00390 & 0.702 \\
\hline 11 & 20 & 0.00334 & 0.00494 & 0.676 & 0.00414 & 0.00586 & 0.706 \\
\hline 12 & 20 & 0.00373 & 0.00551 & 0.678 & 0.00448 & 0.00652 & 0.688 \\
\hline 13 & 20 & 0.00398 & 0.00593 & 0.672 & 0.00480 & 0.00697 & 0.689 \\
\hline 14 & 20 & 0.00431 & 0.00625 & 0.689 & 0.00511 & 0.00725 & 0.705 \\
\hline 15 & 20 & 0.00456 & 0.00650 & 0.703 & 0.00533 & 0.00755 & 0.706 \\
\hline
\end{tabular}

(b)

\begin{tabular}{|c|c|c|c|c|c|c|c|}
\hline \multirow[b]{2}{*}{ Cycle } & \multirow{2}{*}{$\begin{array}{c}\text { Peak load, } \\
\text { kips }\end{array}$} & \multicolumn{2}{|c|}{ Left loaded end slip $^{*}$} & \multirow{2}{*}{$\begin{array}{l}\text { Ratio of high } R_{r} \\
\quad \text { to Conv. }{ }^{\dagger}\end{array}$} & \multicolumn{2}{|c|}{ Right loaded end slip $^{*}$} & \multirow{2}{*}{$\begin{array}{l}\text { Ratio of high } R_{r} \\
\quad \text { to Conv. }{ }^{\dagger}\end{array}$} \\
\hline & & High $R_{r}$, in. & Conv., in. & & High $R_{r}$, in. & Conv., in. & \\
\hline 1 & 10 & 0.00019 & 0.00053 & 0.359 & 0.00011 & 0.00045 & 0.250 \\
\hline 2 & 10 & 0.00019 & 0.00053 & 0.353 & 0.00011 & 0.00050 & 0.213 \\
\hline 3 & 10 & 0.00019 & 0.00058 & 0.323 & 0.00013 & 0.00052 & 0.253 \\
\hline 4 & 10 & 0.00018 & 0.00060 & 0.292 & 0.00013 & 0.00056 & 0.233 \\
\hline 5 & 10 & 0.00018 & 0.00062 & 0.287 & 0.00013 & 0.00059 & 0.222 \\
\hline 6 & 15 & 0.00048 & 0.00106 & 0.451 & 0.00043 & 0.00107 & 0.399 \\
\hline 7 & 15 & 0.00054 & 0.00117 & 0.460 & 0.00048 & 0.00124 & 0.389 \\
\hline 8 & 15 & 0.00062 & 0.00131 & 0.472 & 0.00052 & 0.00132 & 0.395 \\
\hline 9 & 15 & 0.00065 & 0.00138 & 0.470 & 0.00059 & 0.00139 & 0.422 \\
\hline 10 & 15 & 0.00070 & 0.00143 & 0.490 & 0.00061 & 0.00144 & 0.424 \\
\hline 11 & 20 & 0.00121 & 0.00231 & 0.521 & 0.00126 & 0.00223 & 0.564 \\
\hline 12 & 20 & 0.00142 & 0.00283 & 0.503 & 0.00154 & 0.00263 & 0.585 \\
\hline 13 & 20 & 0.00162 & 0.00317 & 0.513 & 0.00175 & 0.00298 & 0.589 \\
\hline 14 & 20 & 0.00182 & 0.00343 & 0.532 & 0.00200 & 0.00324 & 0.619 \\
\hline 15 & 20 & 0.00194 & 0.00366 & 0.531 & 0.00219 & 0.00344 & 0.636 \\
\hline
\end{tabular}

"Average slips from four tests for high $R_{r}$ bars and five tests for conventional bars, respectively.

$\dagger$ Ratio of slip of high $R$ bar to that of conventional bar.

Note: 1 in. $=24.5 \mathrm{~mm}$; 1 kip $=4.448 \mathrm{kN}$.

quake Resistant RC Interior Beam-Column Joints,” Report 78-13, University of Canterbury, Department of Civil Engineering, Christchurch, New Zealand, $96 \mathrm{pp}$.

Ciampi, V.; Eligehausen, R.; Bertero, V. V.; and Popov, E. P., 1982, "Analytical Model for Deformed Bar Bond under Generalized Excitations," Report No. UCB/EERC-82/83, Earthquake Engineering Research Center, University of California at Berkeley, $103 \mathrm{pp}$.

Darwin, D., and Graham, E. K., 1993, "Effect of Deformation Height and Spacing on Bond Strength of Reinforcing Bars," ACI Structural Journal, V. 90, No. 6, Nov.-Dec., pp. 646-657.

Darwin, D.; Tholen, M. L.; Idun, E. K.; and Zuo, J., 1996, "Splice Strength of High Relative Rib Area Reinforcing Bars," ACI Structural Journal, V. 93, No. 1, Jan.-Feb., pp. 95-107.

Durrani, A. J., and Wight, J. K., 1982, "Experimental and Analytical Study of Internal Beam-to-Column Connections Subjected to Reversed Cyclic Loading," Report No. UMEE 82R3, Department of Civil Engineering, University of Michigan, $275 \mathrm{pp}$

Ehsani, M. R. and Wight, J. K., 1982, "Behavior of Exterior Reinforced Concrete to Column Connections Subjected to Earthquake Type Loading,"
Report No. UMEE 82R5, Department of Civil Engineering, University of Michigan, $243 \mathrm{pp}$

Eligehausen, R.; Popov, E. P.; and Bertero, V. V., 1983, "Local Bond Stress-Slip Relationships of Deformed Bars under Generalized Excitations," Report No. UCBIEERC-82/23, Earthquake Engineering Research Center, University of California at Berkeley, $169 \mathrm{pp}$

Leon, R. T., 1989, "Interior Joints with Variable Anchorage Lengths," Journal of Structural Engineering, ASCE, V. 115, No. 9, Sept., pp. 22612275.

Meinheit, D. F., and Jirsa, J. O., 1977. "Shear Strength of Reinforced Concrete Beam-Column Joints," CESRL Report No. 77-1, Department of Civil Engineering, Structures Research Laboratory, University of Texas at Austin, $271 \mathrm{pp}$.

Shu, S., and Jirsa, J. O., 1983, "A Study of Bond Deterioration in Reinforced Concrete Beam-Column Joints," PMFSEL Report No. 83-1, University of Texas at Austin, $69 \mathrm{pp}$.

Zuo, J., and Darwin, D., 1998, "Bond Strength of High Relative Rib Area Reinforcing Bars," SM Report No. 46, University of Kansas Center for Research, $350 \mathrm{pp}$. 